\title{
Books That Inspire, Books That Offend
}

A content analysis of 298 statements describing books included in the University of Oklahoma Books That Inspire exhibit was conducted to identify the reasons members of the academic community found particular books inspiring. Twenty-six recurrent themes in seven concept clusters were identified. Books from the exhibit that have been challenged or censored were examined to compare the perceptions of exhibit contributors and book challengers in the context of those themes. These responses often focused on very different aspects of literary works; however, some relationships did emerge between the reasons books were found variously inspiring and offensive. Findings are analyzed in the context of the academic mission and the role of academic librarians in promoting leisure reading.

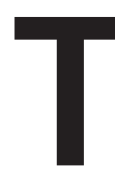
he Books That Inspire (BTI) exhibit began at the University of Oklahoma in 2001 and has continued as an annual event ever since. The exhibit invites members of the university community to celebrate "books that have enlightened, inspired, or influenced the lives and careers of the readers." Its purpose is threefold: to observe National Library Week (during which the exhibit opens), to promote reading, and to call "attention to [books'] power to change and influence lives." The books are displayed for several weeks in the main library on campus (Bizzell Memorial Library) accompanied by short statements from their contributors that explain why they were found meaningful.

The contributed titles represent a wide variety of genres. It is not surprising to find that literary classics are included-great literature, by definition, addresses important themes in texts that are memorable and inspiring and that shape the way people think and feel. It is a bit more surprising to note that a substantial number of the titles are classified as nonfiction, which one might think of as useful and informative, but not necessarily inspiring. However, unexpected definitions of "inspiring" are part of the exhibit's appeal and central to this study's first question: What is a book that inspires? How did contributors interpret the idea of inspiration? The second part of this study focused particular attention on those selections that have been challenged or censored, exploring the idea that some of the reasons the books were celebrated might be thematically related to the reasons they were challenged.

\section{LITERATURE REVIEW}

Budd opens his insightful discussion of the purpose of higher education by

\section{Molly Strothmann and Connie Van Fleet}

\section{Molly Strothmann is Assistant Professor of Bibliography and Social and Behavioral Sciences Librarian, University of Oklahoma Libraries, Norman. Connie Van Fleet is Professor, School of Library and Information Studies, University of Oklahoma, Norman. Submitted for review December 31, 2008; accepted for publication February 25, 2009.}

Reference \& User Services Quarterly, vol. 49 , no. 2 pp. 163-179 (c) 2009 American Library Association. All rights reserved.

Permission granted to reproduce for nonprofit, educational use. 
addressing liberal education, which he defines in the classic sense:

Liberal education is directed at a full appreciation of art, literature, society, and science-first for their connections to us as rational-emotional beings, and then for their contribution to everything we do as humans. In a sense, higher education ... . intends those within the institution to explore, communicate, and experience reality to grow most fully as individuals. ${ }^{2}$

Academic librarians have long recognized the important role that reading plays in contributing to that academic mission. In particular, leisure reading fosters learners who carry the habits of thoughtful reflection and active participation with them throughout their lives, prompting recent discussion of the ability of academic libraries to support and encourage this enriching activity. ${ }^{3}$

\section{Students' Reading Habits}

Several surveys have reported a decline in reading among college-age individuals. Hendel and Harrold found that undergraduates in 2001 devoted less time to leisure reading than in the previous three decades, spending far more time with e-mail or on the Internet than reading books. ${ }^{4}$ In Reading at Risk, the National Endowment for the Arts expresses concern for declining levels of literary reading in all age groups, but particularly young people ages 18-24, citing a negative effect on civic and cultural participation. The 2004 report notes, however, that education is the primary predictive factor, with 74 percent of those with a graduate school education reading literary works as compared to only 14 percent of adults with a grade school education. ${ }^{5}$ Quite unexpectedly, the NEA's 2009 Reading on the Rise reports that the decline in reading among adults has reversed, with the first rise in adult reading since 1982 . The strongest gain is among young adults, who showed a 21 percent increase over the earlier survey. ${ }^{6}$

For college students, the single greatest barrier to leisure reading may be lack of time, not lack of interest. Although the heading "The Lost Art of Literature" in a 2007 article in the Chronicle of Higher Education implies that a "new generation of wellwired multitaskers" do not read, nine of the ten student respondents reported having read a book for pleasure within the past year, with four reporting having last finished a book over the summer. ${ }^{7}$ Burak found that the majority of college students read for pleasure, most frequently during summers and other breaks. ${ }^{8}$ This pattern tends to reinforce Von Sprecken and Krashen's finding that children do not lose interest in reading as they age; there are just more competing activities. ${ }^{9}$

\section{Why People Read}

Typically, when people are asked why they read, they say it is for escape, for stimulation, or for greater understanding of themselves or the world around them. Further, research from a number of disciplines suggests that leisure reading has physiological, psychological, social, and cognitive effects on people. ${ }^{10}$ Recent work in readers' advisory emphasizes the value of reading as a means of "incidental" or "accidental" learning and notes the importance of nonfiction, particularly narrative nonfiction, in meeting the needs of leisure readers. ${ }^{11}$

Many authors have examined motivations for reading. Ross gives a cogent summary of the reasons people read:

Over and over, in published studies and in the interviews with readers in my own study, readers say: books give me comfort, make me feel better about myself, reassure me that I am normal and not a freak because characters in books have feelings like mine. Books provide confirmation that others have gone through similar experiences and survived. Books help me clarify my feelings, change my way of thinking about things, help me think through problems in my own life, help me make a decision, and give me the strength and courage to make some major changes in my own life. They give me a sense of mastery and control, give me courage to fight on, make me think that if the hero(ine) can overcome obstacles, then so can I, give me the hope to rebuild my life, and help me accept things I cannot change. They put me in touch with a larger more spacious world. In summary, books provide a special kind of pleasure that cannot be achieved in any other way. ${ }^{12}$

\section{Why People Challenge Books}

The grounds on which people challenge books are thoroughly discussed in the literature, notably by the Facts on File Banned Books series, which does an admirable job of categorizing books on the basis of challenges for social, sexual, political, or religious content. ${ }^{13}$ Censors often fail to view 
literature holistically, concentrating on specific words or scenes as objectionable instead of evaluating the merit of a work as a whole. ${ }^{14}$

While content including sex, profanity, or religious viewpoints may catalyze challenges, the underlying motivations of censorship attempts are often more complex. ${ }^{15}$ Cain notes that "some censors have low tolerance for diversity, ambiguity and conflict, because they see these things as dangerous to order and stability."16 Avid defenders of the First Amendment embrace the very traits that would-be censors reject, believing that "disagreement and controversy are not only inevitable, but desirable, the very life-blood of all intellectual and cultural activity." ${ }^{\prime 7}$

\section{Summary}

Lee's introduction to the 2002 exhibit suggests that books that inspire may also offend: "[Books] liberate us from the narrowness that tradition and society impose. ... This is the power of books-a power that some societies fear and, consequently, they seek to restrain access to books and the ability to read. We are fortunate to live in a society that recognizes and appreciates the value of books and reading." 18

The mission of higher education is to promote individual enrichment and community engagement. Studies demonstrate that students continue to participate in recreational reading despite time constraints and that leisure reading correlates strongly with student achievement in the short-term as well as long-term success and civic participation. Academic librarians recognize the connection between leisure reading and the academic mission and have developed library services that support or encourage leisure reading. Understanding the value of leisure reading, the qualities that make books inspiring, and the reasons controversy attaches to them may give academic librarians a new understanding of readers' advisory services in academic libraries and the extent to which those services can support the mission of higher education.

\section{METHOD}

Observing the University of Oklahoma Libraries' annual BTI exhibit prompted two questions: (1) What are the reasons people find certain books inspiring? and (2) Are there any relationships between those reasons and the reasons that those same books have been challenged or censored?

This study, which is concerned with the leisure reading interests and motivations of members of the academic community, used the contributions to the Books That Inspire exhibit as a convenience sample. The study included the books from the first five exhibits (2001-05) and the seventh (2007). The 2006 "encore exhibit" of selected entries from previous years was omitted. This yielded 298 entries discussing 277 titles, with 13 books having been contributed twice by different people and 4 books, 3 times. Members of the University of Oklahoma faculty contributed 179 of the entries; non-athletics staff, 91; members of the Athletics Department, 28. In recognition of the state's 2007 centennial activities, the seventh exhibit highlighted books either about Oklahoma or written by Oklahoma authors; otherwise, contributors were free to nominate books of any type.

The BTI contributors' statements about their books were studied using content analysis techniques to determine why they were viewed as inspiring. For the books that had been the object of censorship, the exhibit statements and the literature on the challenges were compared to ascertain if there were any similarities between the reasons that they were deemed variously offensive and inspiring.

First, cases of the books having been banned, censored, challenged, prohibited, or suppressed were researched. This article generally refers to those books as having been "challenged," but intends the term broadly: Cases ranged from official state suppression to single complaints at school or public libraries. Searching for challenges included consulting approximately 20 encyclopedias and anthologies on censorship, obtaining the references that those sources cited, and searching in relevant databases for news or research articles mentioning challenges. ${ }^{19}$ Challenges were found for 48 entries (38 unique titles). A graduate research assistant reviewed the resultant literature and excerpted key words and phrases that explained the reasons for each challenge.

The researchers then independently examined the BTI contributors' statements, conducted a content analysis of all 298 statements, and jointly through an iterative process developed a vocabulary to describe the themes that emerged. These themes were not defined with reference to any preexisting framework; rather, they were developed a posteriori from the text of the contributors' statements. Finally, similar or related themes were grouped together and organized into overarching concepts.

As a precaution against bias, the researchers minimized their exposure to the located literature about challenges (including the keywords selected by the graduate research assistant) as much as pos- 
sible until having completed this process. Only after the themes were finalized did the researchers review that literature and examine the underlying reasons for the challenges. The reasons for the challenges were compared to the themes that had emerged from the BTI contributors' statements for each of the forty-eight challenged entries. (Wherever possible, the researchers examined the original language used by challengers rather than that of commentators; however, some analyses by third parties were also included in the study.) The hypothesis driving the comparison was that inspired readers and offended readers would likely emphasize similar aspects of a given work, but would differ markedly in their framing, the former celebrating aspects that the latter condemned. Finally, the frequency with which each theme occurred in challenged and unchallenged books' statements was compared to determine if there were any trends differentiating the two groups.

\section{FINDINGS}

The analysis of the BTI contributors' statements revealed twenty-six major recurrent themes. Those themes clustered into seven major concepts: the connection between the book and its reader, relationships and understanding others, the individual in society, self-improvement and living righteously, worldview or philosophy, intellectual influence and appeal, and readership. The identified themes appeared in as few as 3 ( 1 percent) to as many as 100 (34 percent) of the 298 statements. Table 1 indicates the frequency with which each theme emerged from the challenged and unchallenged books' statements.

Challenges were found for forty-eight entries to the exhibit (thirty-eight unique titles). Of those, six appeared on the list of "100 Most Frequently Challenged Books of 1990-2000" compiled by the American Library Association's Intellectual Freedom Committee: The Adventures of Huckleberry Finn (no. 5), Kaffir Boy (no. 31), To Kill a Mockingbird (no. 41), The Outsiders (no. 43), Native Son (no. 71), and Bless Me, Ultima (no. 75). ${ }^{20}$ Compared to the unchallenged books, challenged books were much more likely to be fiction and to appear on the College Board's "101 Great Books Recommended for College-Bound Readers" (see table 2). ${ }^{21}$

The hypothesis that similarities would be observed between the reasons the books were considered inspiring and the reasons they were challenged was partially supported because such a similarity was observed in many of the challenged titles. In cases that did not show a direct correspondence, the inspired and the offended tended to evince a difference in focus as readers: While the former concentrated on the overall themes or merit of the books, the latter concentrated on specific narrow aspects of them, such as offensive language or sexual explicitness.

Quotes from the BTI contributors' statements used throughout this section were obtained from the annual booklets made available at the exhibit. (The statements also are available online at http:// libraries.ou.edu/exhibits.) Parenthetical citations provide the number of the exhibit that included the quoted contribution; asterisks indicate challenged books. Endnote citations are provided for the quoted challenges, which are exemplary, rather than inclusive, of the book challenges found.

\section{Concept 1: Connection between Book and Reader}

The first major concept that emerged from the BTI statements addressed the relationship between book and reader. The themes within this concept spoke to the idea that what made a book meaningful was a sense of a direct connection between the text and the reader's own life-a book that spoke to its reader personally. Books that reached their readers just when they were most needed, books that seemed to echo their contributors' own experiences or interpret nascent impressions better than they had yet expressed them, and books that provided cherished emotional support were all popular interpretations of "books that inspire."

\section{Timeliness/Age Appropriateness}

Statements with this theme emphasized that their books were meaningful specifically because they were read at a particular point in their contributors' lives. Most referred to the contributors' ages, whether they read literature that instilled a love of reading in childhood, nonfiction that influenced a career path in early adulthood, or in a few cases, books that provided guidance as their contributors navigated middle age. However, a few contributors celebrated books not because they reached them at the ideal age, but because the circumstances of their lives made them particularly timely. These books satisfied immediate emotional needs or somehow answered the concerns of the moment for their readers.

I experienced the novel To Kill a Mockingbird by Harper Lee during an impressionable pe- 
Table 1. Themes Occurring in BTI Statements Referring to Challenged and Unchallenged Books

\begin{tabular}{|c|c|c|c|}
\hline & $\begin{array}{l}\text { Challenged } \\
\qquad(N=48)\end{array}$ & $\begin{array}{l}\text { Unchallenged } \\
\qquad(N=250)\end{array}$ & $\begin{array}{c}\text { Total } \\
(\mathbf{N}=298)\end{array}$ \\
\hline \multicolumn{4}{|l|}{ Connection Between Book and Reader } \\
\hline Timeliness/age appropriateness—childhood & $9(19 \%)$ & $18(7 \%)$ & $27(9 \%)$ \\
\hline Timeliness/age appropriateness_early adulthood & $3(6 \%)$ & $24(10 \%)$ & $27(9 \%)$ \\
\hline Timeliness/age appropriateness_-later adulthood & 0 & $3(1 \%)$ & $3(1 \%)$ \\
\hline Timeliness/age appropriateness_life events & $1(2 \%)$ & $13(5 \%)$ & $14(5 \%)$ \\
\hline Resonance & $5(10 \%)$ & $23(9 \%)$ & $28(9 \%)$ \\
\hline Positive emotional value & $1(2 \%)$ & $26(10 \%)$ & $27(9 \%)$ \\
\hline \multicolumn{4}{|l|}{ Relationships and Understanding Others } \\
\hline Common humanity and universality & $3(6 \%)$ & $7(3 \%)$ & $10(3 \%)$ \\
\hline Empathy with other experiences & $4(8 \%)$ & $5(2 \%)$ & $9(3 \%)$ \\
\hline Unheard voices and diversity & $10(21 \%)$ & $47(19 \%)$ & $57(19 \%)$ \\
\hline Relationships between individuals & $5(10 \%)$ & $14(6 \%)$ & $19(6 \%)$ \\
\hline \multicolumn{4}{|l|}{ Individual in Society } \\
\hline Anti-authoritarianism or independent thought & $6(13 \%)$ & $4(2 \%)$ & $10(3 \%)$ \\
\hline Social critique & $11(23 \%)$ & $36(14 \%)$ & $47(16 \%)$ \\
\hline Social progress/affirmative social critique & 0 & $9(4 \%)$ & $9(3 \%)$ \\
\hline \multicolumn{4}{|l|}{ Self-Improvement and Living Righteously } \\
\hline Heroes and role models & $9(19 \%)$ & $65(26 \%)$ & $74(25 \%)$ \\
\hline Life lessons & $10(21 \%)$ & $64(26 \%)$ & $74(25 \%)$ \\
\hline Morals and values & $10(21 \%)$ & $30(12 \%)$ & $40(13 \%)$ \\
\hline Introspection/self-examination & $3(6 \%)$ & $23(9 \%)$ & $26(9 \%)$ \\
\hline \multicolumn{4}{|l|}{ Worldview or Philosophy } \\
\hline Provided insight or shaped worldview & $14(29 \%)$ & $45(18 \%)$ & $59(20 \%)$ \\
\hline Challenged own worldview/expanded horizons & $8(17 \%)$ & $20(8 \%)$ & $28(9 \%)$ \\
\hline \multicolumn{4}{|l|}{ Intellectual Influence and Appeal } \\
\hline Intellectually inspiring/factual learning & $11(23 \%)$ & $89(36 \%)$ & $100(34 \%)$ \\
\hline Professionally inspiring & $3(6 \%)$ & $76(30 \%)$ & $79(27 \%)$ \\
\hline \multicolumn{4}{|l|}{ Readership } \\
\hline Aesthetic and literary value & $15(31 \%)$ & $44(18 \%)$ & $59(20 \%)$ \\
\hline Emotional response to book & $9(19 \%)$ & $29(12 \%)$ & $38(13 \%)$ \\
\hline Canonical value of book & $8(17 \%)$ & $9(4 \%)$ & $17(6 \%)$ \\
\hline Inspired further reading & $9(19 \%)$ & $11(4 \%)$ & $20(7 \%)$ \\
\hline Revisitable & $7(15 \%)$ & $23(9 \%)$ & $30(10 \%)$ \\
\hline
\end{tabular}

riod of my life, my early teens. (BTI II)*

While full astride my mid-life crisis, I accidentally read The Denial of Death by Ernest Becker. . . . It became the perfect bibliotherapy for me as a forty-two year old American male. (BTI III)
I really enjoyed Tuesdays With Morrie specifically because of the timing in which I read it. My grandmother was in her last days of life. (BTI III)

This theme is more easily examined by separating those statements that referred to childhood 
Table 2. Comparison between Challenged and Unchallenged Books

\section{Challenged}

48 entries, 38 unique titles

36 entries (75\%), or 28 titles, were fiction

12 entries (25\%), or 10 titles, were nonfiction

20 entries (42\%), 14 titles, included on "101 Great Books Recommended for College-Bound Readers": The Adventures of Huckleberry Finn, All Quiet on the Western Front, Crime and Punishment, Don Quixote, Emerson's Essays and Lectures: "Essays: First Series," The Grapes of Wrath, Invisible Man, Native Son, The Odyssey, One Hundred Years of Solitude, A Portrait of the Artist as a Young Man, Chekhov's Selected Stories ("The Cherry Orchard" specifically is included on the list), A Tale of Two Cities, and To Kill a Mockingbird

\section{Unchallenged}

250 entries, 239 unique titles

64 entries (26\%), or 62 titles, were fiction

186 entries (74\%), or 177 titles, were nonfiction

6 entries (2\%), 5 titles, included on "101 Great Books Recommended for College-Bound Readers": Portrait of a Lady, Pride and Prejudice, The Three Musketeers, To the Lighthouse, and Walden reading from those that mentioned life events or other ages. The majority of statements that made reference to timeliness in adulthood described unchallenged books, as did those statements that mentioned the theme in relation to the reader's life events (see table 1 for details). For the few challenged books, no relationship was found between this inspirational theme and the reasons the books were challenged.

Statements that described their titles as particularly meaningful to the contributor for having been read in childhood or adolescence were quite different. The theme appeared in a larger percentage of BTI entries referring to challenged books (19 percent, 9 statements referring to 8 unique titles) than unchallenged ( 7 percent, 18 statements), and the converse of this theme emerged quite strongly in the challenges: Age-specific objections were raised directly in the challenges to five of the eight titles. For instance, To Kill a Mockingbird, whose BTI entry is quoted above, was challenged as "unfit for use in the junior high school."22

\section{Resonance}

Statements with this theme spoke of a sense of likeness between the reader and the text, reflecting their contributors' own beliefs, emotions, or experiences. Some contributors implied that seeing their experiences echoed in literature had helped to clarify or legitimize them, while others simply relished the commonality.

Notes from Underground gave shape to emotions I had often felt, but had never before seen acknowledged by anyone else. (BTI IV)*
[Invisible Man] prompted a feeling of commonality more so than one of inspiration for me. . . [Ellison's] creative prose is reminiscent of many conversations held in the neighborhood where I grew up. During these discussions the state of the world was often evaluated, and included much "street philosophy" about the plight of "invisibility." (BTI II)*

[I Don't Know How She Does It: The Life of Kate Reddy, Working Mother] validated personal feelings that I had regarding my own career versus the adventures of motherhood. It made me feel like I was not alone. (BTI III)

The percentage of challenged books (10 percent, 5 statements) and unchallenged books (9 percent, 23 statements) whose statements addressed the idea of resonance was approximately the same. A contributor explained her connection with J. D. Salinger's Franny and Zooey: "I knew Franny's plight intimately: tired of dating pompous boys, exhausted with pedants, bored with conformity, and hungry for meaning" (BTI III). The challenger, conversely, saw not "teenage angst" and a reflection of a thoughtful young person's life, but "characters too concerned with sex." ${ }^{23}$ Challenges to books in this category did not engage the idea of resonance directly. However, the focus on graphic aspects-too much violence, too much sexual content - that appeared in connection with three of the five challenged books may be viewed as denying commonality between these books and the challengers who were offended by them. 


\section{Positive Emotional Value}

Readers mentioning this theme found comfort, encouragement, uplift, or optimism from their books. This theme was broad, encompassing practically any positive emotional reaction to the text (as opposed to the writing, which is discussed below).

Whenever I felt overwhelmed or sad, I simply remembered the philosophy of the verses, or I read [Gitangali] again for the purification of my soul. (BTI V)

At the end, [ISurvived Cancer, But Never Won the Tour de France] made me feel stronger. (BTI VII)

Only one statement about a challenged book (The Giving Tree, BTI V) incorporated this upbeat theme, which appeared in statements for twentysix (10 percent) of the unchallenged books. The reason for the challenge-sexism-does not relate to the positive emotional value cited by the contributor. $^{24}$

\section{Concept 2: Relationships and Understanding Others}

The first concept was about the relationship between reader and book; concept 2 is about books' ability to provide insight into relationships between individuals. Statements with the four themes in this concept describe books that taught their readers to understand other people better.

\section{Common Humanity and Universality}

These books had the ability to create common ground between the reader and a subject that was alien to the reader's own personal experiences. Statements in this category described books that reminded their contributors of human interdependence and that reflected truths that applied to all people, regardless of setting or circumstance.

In The Analects, Confucius holds the mirror of our own humanity up to us across two and a half millennia. (BTI IV)*

From Slavery to Freedom . . . explained the historical importance of that struggle to American society and that black history isn't just for black Americans, but for all Americans. (BTI VII)
Inspirational statements for challenged books incorporated this theme at twice the rate of unchallenged books ( 6 percent, 3 statements to 3 percent, 7 statements). One would not expect this theme to occur often as grounds for censorship; however, one direct association between inspirational statement and challenge was found. In The Analects of Confucius, the Chinese Communist Party identified not common humanity, but divisiveness, because "Confucian thinking ... promot[ed] an ideology of exploitation, elitism, social hierarchy, and preservation of a status quo in which people knew and kept their place in a static society and obeyed the prescribed rites for their station in life."25

\section{Empathy with Other Experiences}

While the preceding theme celebrated commonalities, this one honored differences. These books taught their contributors to appreciate perspectives besides their own and to refrain from assuming that their own experiences were universal. These books broadened their readers, helping them learn to understand others.

I grew up in northern Canada and only knew about the African-American experience by watching Roots on television. I was moved by the miniseries, but this book allowed me to experience the "hate stare" and to feel unwanted. . . An aside: my adopted sister is Indian and Black Like Me also helped me to understand why her life experiences would always be different from mine. (BTI I)*

Sometimes a good book goes unappreciated because the reader has not yet reached the place where the story resides. However, some books are so powerful that they pull you in and teach you things beyond your experience. Cry the Beloved Country was such a book for me. (BTI I)

The empathy theme was included at a much higher rate in the statements referring to challenged books ( 8 percent, 4 statements) than unchallenged ( 2 percent, 5 statements). As the challenges to Black Like Me demonstrate, the converse of empathy may take several different forms. An outright and specific rejection of the other is perhaps the most antithetical concept to empathy, bluntly summarized by the observer who noted, "In my opinion the objections in most cases were because of black people being in the book." ${ }^{26}$ Denial of the accuracy (or reality) of the depiction is another converse of empathy found among the 
challenges to this book-many claimed "it did not accurately reflect the reality of the southern social situation." 27

\section{Unheard Voices and Diversity}

These books gave voice to a perspective or experience that the contributor felt was often forgotten. Many dealt specifically with themes of diversity and explored issues of race, nationality, gender, or sexual orientation. Readers valued them because they represented points of view that might otherwise be silenced, marginalized, or ignored.

For many of us, Bless Me, Ultima is a special book, the first book to establish a vision of the Chicano world and to define many of the terms for understanding the MexicanAmerican experience. (BTI III)*

[Invisible Man] added a heretofore unheard black point of view to the dialogue on 1950s race issues in America. (BTI I)*

Despite the global nature of our societies today, the history of world architecture is still dominated by Eurocentric ideologies. African Architecture Evolution and Transformation by Nnamdi Elleh presents a concise history of African architecture. (BTI II)

This theme was the most frequently occurring within this concept, appearing in 10 (21 percent) challenged books' statements and 47 (19 percent) of the unchallenged. Challenges likewise addressed this theme, often by rejecting the challenged book's perspective. One reader of To Kill a Mockingbird appreciated its "lessons on courage, racial prejudice, and fear of the different" (BTI II). Burress notes, conversely, that between 1965 and 1977, To Kill a Mockingbird was among those opposed specifically "because [it] depicted minority group people in ways that constituted a vigorous protest against racism." 28 The reader who contributed The Adventures of Huckleberry Finn to the exhibit discussed the "anti-racist message of the book" and Huck's ability to "transcend the awful ignorance of his time" (BTI II), while the frequent modern challenges to the book on the basis of racism bespeak a very different interpretation of its relationship to the value of diversity. ${ }^{29}$

\section{Relationships between Individuals}

These books resonated with their contributors for their insight into interpersonal relationships. The theme encompasses both the prescriptive (how people should behave toward and interact with one another) and the descriptive (depictions of warm or appealing interpersonal relationships that the contributors found inspiring).

[Discussing I and Though] Our most human relationships are not those in which we exchange value, but rather those in which we share our being. (BTI IV)*

Big Fish is a story of a great life lived and a great way to die, the bonding of a father and son and the love of a good tale. (BTI V)

Fast Food Nation inspired me to walk into my bank and speak to the tellers, to write letters instead of e-mail and to discover and patronize "Mom and Pop" restaurants and shops. I feel like I am becoming a part of my community. (BTI III)

A greater percentage of statements referring to challenged books ( 10 percent, 5 statements) than those referring to unchallenged ones (6 percent, 14 statements) incorporated this theme. Both BTI statements on The Analects of Confucius (contributed twice) referred to interpersonal relationships in terms of the interconnectedness of individuals in human society (BTI II, IV). As mentioned above, leaders of the Chinese Communist Party, who interpreted Confucian philosophy differently, criticized the Analects for the model of interpersonal relationships and social structure that Confucianism promoted. This theme did not, however, emerge among the challenges to the other books whose BTI statements incorporated it.

\section{Concept 3: Individual in Society}

The next group of statements also considered a form of relationships, discussing their books' perspectives on the interaction between the individual and society. Some of these books provided models of independent thinking that the contributors cited as important to their own ethical or intellectual development. Others inspired readers by perceptively criticizing the dominant culture. As with many of the other categories, these statements ranged from very specific to general: Some contributors remarked on books that opened their eyes to a single societal failing (such as racism, a recurrent example), while others extrapolated social critique as a virtue in itself, praising books that inculcated in them the intellectual habit of independent thinking. 


\section{Anti-Authoritarianism or Independent Thought}

Statements with this theme discussed books that either modeled anti-authoritarianism or independent thinking or encouraged the contributor to embrace those traits. Any statement implying that there might be virtue to be found in nonconformity or rebellion fell into this category.

[Don Quixote] teaches me that everything is subjectively perspectival and temporary; nothing is permanent or absolutely objective. . . This baroque lesson might cause some trepidation; but also joy, for everything becomes then a matter of perception: a possibility, a choice. Like Don Quixote, I too choose my perspective, my truth. (BTI I)*

[Commodify Your Dissent] encourages readers to be enlightened consumers and to resist corporatization of the mind (BTI IV).

Reading West [Democracy Matters] teaches me how to grow habits of critical engagement. You learn to think for yourself, to render authorities subject to your own suspicion, and to work toward the awakening of your own soul. (BTI VII)

This theme appeared at a much greater rate in statements referring to challenged books (13 percent, 6 statements) than in those referring to unchallenged books ( 2 percent, 4 statements). Three of the six challenged books (The Castle, Don Quixote, and On the Origin of Species) have been officially banned by either an agency of government or by the Catholic Church. ${ }^{30}$ As official suppression is itself a stark demonstration of authoritarianism, those bans are considered the converse of this theme. The case of Don Quixote could not be more clear a contrast: While its contributor emphasized the value of subjectivity and personal choice, in 1981 the Chilean military junta banned the book "as subversive because it supports individual freedom and attacks authority." 31

\section{Social Critique}

Statements with this theme praised books that evaluated society or social conditions. Contributors found them inspirational either because they opened their eyes to specific failings in the world around them or because they taught the habit of critical examination of one's world. These inspirational statements framed the social critique in terms of such topics as war (All Quiet on the Western Front, BTI II); politics and science (Cat's Cradle, BTI I, V); education (Émile, BTI V); and race (The Adventures of Huckleberry Finn, BTI II; Invisible Man, BTI I, II, IV; and Native Son, BTI II). A small number of contributors chose books that critiqued their milieus but-unlike the majority of books with this theme-drew positive or optimistic conclusions. Many of those statements described their books as depicting examples of successful social progress and indicated that they inspired their contributors to believe in the possibility of further such progress.

Cat's Cradle is the ultimate exposition of the uneasy balance between the seemingly pure motives of science and the naively corrupt purposes technocrats, politicians, and militarists apply to the products of science. (BTI I)*

Woody Guthrie's Bound for Glory raised my social consciousness several notches when it was thrust upon me by a fellow soldier 45 years ago in California . . I remain a lover of his music and a person concerned with social justice and the way the poor are treated. (BTI VII)

A greater percentage of statements referring to challenged books (23 percent, 11 statements) than those referring to unchallenged books ( 14 percent, 36 statements) incorporated this theme. The positive variation, "affirmative social critique," appeared only in the unchallenged books' statements, in 9 cases (4 percent). The language of the challenge was sometimes a nearly exact match for that of the BTI statement. For instance, All Quiet on the Western Front was perceived as antiwar by both the contributor and by challengers. But while the contributor believed this antiwar perspective was inspiring and thought-provoking ("the finest anti-war novel I have ever read . . . a sobering book [that] addresses the lost innocence of the WWI generation" [BTI II]), All Quiet was banned by Italy as antiwar propaganda and burned in Germany as "slanderous to [Nazi] ideals of home and fatherland." In the United States, it received "challenges on the grounds of its being 'too violent' and for its depiction of war as 'brutal and dehumanizing." 32 The contributor of Native Son found its social critique enlightening, noting that "it is the choices made for him, by fate and society, that led him to the electric chair" (BTI II). Some challenges to it, however, rejected the vehemence of the critique, objecting to "the level 
of rage and anger that the protagonist projects toward white liberals, and Wright's open indictment of American racism." 33

\section{Concept 4: Self-Improvement and Living Righteously}

Statements with the themes in this group interpreted the concept of inspiration as referring to books that helped their contributors to become better people. Focusing on the reader's internal self, these books helped their readers to develop their moral systems, provided role models for them to admire, and encouraged them to examine themselves. These were books that taught their readers how to live.

\section{Heroes and Role Models}

Statements with this theme singled out characters or authors that served as examples to their contributors. They modeled qualities that the contributors found extraordinary and hoped to emulate.

Each time I read [The Grapes of Wrath] I am touched by the determination, humanity, and courage of the people from Oklahoma. (BTI VII)*

Laura [from On the Banks of Plum Creek] was my hero. She slept in a dugout, survived a grasshopper plague, and braved hailstorms and blizzards. The Little House books taught me that girls could be adventuresome and courageous — and that they could be writers when they grew up. (BTI I)

The third most frequently occurring theme in the exhibit, "Heroes and Role Models" appeared in a higher percentage of statements about unchallenged books (26 percent, 65 statements) than about challenged books (19 percent, 9 statements). Contributors perceived these characters as worthy of admiration; the converse, viewing them as unworthy, appeared frequently among the challenges to The Grapes of Wrath. Challengers found its characterization offensive and misleading. One called it "demeaning to Southerners," while another said

The Grapes of Wrath has offended our citizenry by falsely implying that many of our fine people are a low, ignortant [sic], profane and blasphemous type living in a vicious and filthy manner, and ... Steinbeck presents our public officials, law enforcement officers and civil administrators, business men, farmers, and ordinary citizens as inhumane vigilantes, breathing class hatred and divested of sympathy or human decency or understanding. ${ }^{34}$

Other challenges hinged on the viewpoint that these characters-whatever good qualities they might have-evince values of which censors disapprove. Ulysses may have been "the smartest and shrewdest of the Greek heroes that fought in the Trojan War" (BTI V), but the "Greek ideals of freedom" that his Odyssey expressed were sufficient to prompt Caligula to attempt to suppress it. ${ }^{35}$

\section{Life Lessons}

Whether by embracing the priorities that the books argued were most meaningful or by following the examples of virtue that they portrayed, contributors felt that they could live better, more righteously, more fully by taking these books to heart. The lessons were diverse, but they shared the common element of teaching their readers how to improve themselves.

I've lost count of the number of times in which "Trust thyself: every heart vibrates to that iron string" [from Emerson's Essays and Lectures] has guided me toward what is real and right. (BTI II)*

[The Old Man and the Sea] serves to remind me to think about the greater good I'm working toward, rather than the sometimes unpleasant tasks that are part of the process. $($ BTI V)*

[Walden] always reminds me of the folly of mindless materialism. (BTI II)

"Life Lessons" tied with "Heroes and Role Models" as the third most frequently occurring theme, and it too appeared in a higher percentage of statements that referred to unchallenged books ( 26 percent, 64 statements) than challenged (21 percent, 10 statements). Most of the challenges found for these books did not have a direct correspondence to the inspiring lesson that the contributors identified. However, one challenge to The Outsiders is directly oppositional. The contributor asserts that the book "teaches us to look beyond social boundaries" (BTI VII). Many challenges refute that lesson specifically: "The whole treatment of class conflict in The Outsiders has been the subject of frequent reactionary criticism. The story, after all, is told by a member of the underclass." 36 


\section{Morals and Values}

These books modeled virtues and shaped their readers' moral thinking. Many of them were credited with helping their contributors to develop their ethical systems and priorities.

[All Quiet on the Western Front] extols the important virtues of duty, honor, friendship, and family. (BTI II)*

[On Liberty] left me with a strong sense of the value of freedom and the dangers of censorship. (BTI I)

Both my respect for labor and my distaste for privilege are anchored in this study of English mining-town poverty [The Road to Wigan Pier]. (BTI V)

This theme appeared in BTI statements referring to challenged books (21 percent, 10 statements) at a higher rate than in those statements referring to unchallenged books (12 percent, 30 statements). The challenges again seem to arise from a matter of interpretation and focus. It is not that challengers reject the morals or values ascribed to these books; rather, they do not interpret them as representing those values. For example, while the three contributors of To Kill A Mockingbird (BTI II, IV) describe a book embodying values of dignity, courage, racial equality, and common humanity, challengers charged the book "represents institutionalized racism under the guise of "good literature," and that "the setting dehumanizes the African-American child. It is belittling to the African-American student and race. ${ }^{" 37}$ The contributor who saw in Émile, or On Education "a treatise on the importance of education for shaping good citizens" (BTI II) disagreed, across centuries, with the archbishop of Paris who condemned it shortly after its publication for its "abominable doctrines." In many cases, such as that of All Quiet on the Western Front, charges that a book was vulgar precluded recognition of other moral value. ${ }^{39}$

\section{Introspection/Self-Examination}

These statements praised books specifically for encouraging their readers to reflect on themselves, to consider their behavior and their moral understanding, to resist self-satisfaction, and to attempt to better themselves accordingly.

Read [The Giving Tree] now, and in every season of your life, and reflect on whether you are giving back as much as you have received. (BTI V)*

[Callings: Finding and Following an Authentic Life] challenged me to examine what I do, how I do it, and why. (BTI I)

Only 9 percent of all statements incorporated this theme. It appeared at a greater rate in statements referring to unchallenged books ( 9 percent, 23 statements) than challenged (6 percent, 3 statements). None of those challenges' grounds directly mirrored this inspirational theme.

\section{Concept 5: Worldview or Philosophy}

Statements with the next two themes celebrated books that had had a special influence on their contributors' understanding of the world. Books with the capacity to shape one's outlook-to explain the world for their readers—-were deeply valued.

\section{Provided Insight or Shaped Worldview}

A major interpretation of "books that inspire" was "books that teach." Contributors of all types of books_challenged and unchallenged, popular fiction and specialized scholarly texts-mused on what they had learned from their chosen books. Unsurprising, then, that the lessons cited varied as widely as did the nominated titles. Statements with this theme spoke of books that taught their readers how to view the world, imparting insights that went beyond the factual to shape the contributors' attitudes toward and understanding of their subjects. As with so many of the other categories, these lessons ranged from the specific (books that formed their contributors' understanding of a given topic) to the fundamental (books that shaped their contributors' basic understanding of society or human nature).

Kafka [in The Castle] illustrates how unidentifiable organs of power really do ultimately control every aspect of our lives, down to the most intimate detail. (BTI I)*

[Framework for Understanding Poverty showed that] schools operate from middleclass norms with hidden rules. Children from poverty come to school with a completely different set of hidden rules. What an eye opener! (BTI III)

This theme appeared in a higher percentage of statements referring to challenged books (29 
percent, 14 statements) than unchallenged (18 percent, 45 statements). The idea of shaping one's worldview was not in and of itself condemned, but specific worldviews were often the subject of suppression when they offended those in authority. Kafka's worldview was "branded as decadent and defeatist when Communists seized power in Czechoslovakia in 1948." ${ }^{40}$ A contributor who named On the Origin of Species noted, "Reading Darwin opened my mind to a new way of thinking about the world. It gave me an exciting insight into how scientists think and reason, and helped me understand that change, both biological and human, is inevitable, but unpredictable" (BTI I). This new worldview "aroused immediate and passionate disagreement, was placed on the Catholic Index Librorum Prohibitorum, and continues to be the subject of censorship in the schools of certain American states and in Islamic countries." ${ }^{41}$ Don Quixote, whose BTI contributor concentrated on the book's openness to subjectivity, was "placed on the Spanish Index for a single sentence... 'Works of charity performed negligently have neither merit nor value," for its hint of Lutheran beliefs - an example of censor and inspired reader displaying the same theme despite focusing on markedly different aspects of their books. ${ }^{42}$

\section{Challenged Own Worldview/Expanded Horizons}

Many contributors appreciated books that opened their eyes to important issues that they had never previously considered, a theme closely connected to the widespread appreciation of books that taught something to their readers. Some of the statements with this theme went beyond recognizing books that broadened their contributors' horizons and specifically praised those that challenged their preexisting worldviews.

[Grendel] tests one's ability to take a critical look at self, society, beliefs. It challenges us to feel sympathy and understanding for what we would normally despise, laugh at what we would normally take gravely serious, and challenge what ideals we would normally accept blindly. Grendel challenges you to question, learn, grow, understand, and think. (BTI IV)*

My father was an English immigrant from a coal mining family in Cumberland. A proud socialist member of the British Labour Party, he taught me that the socialists were all good guys fighting the fascists who were all evil. Ortega y Gasset's [The Revolt of the Masses], encountered in my freshman year, made a compelling case that all mass movements shared common virtues and vices. (BTI II)*

[Highbrow/Lowbrow: The Emergence of Cultural Hierarchy in America] transformed my attitude about being an artist in the United States today. (BTI I)

This theme appeared less frequently than the previous theme, occurring in only 9 percent of all BTI statements. As with "Provided Insight or Shaped Worldview," this theme appeared in a greater percentage of statements referring to challenged books ( 17 percent, 8 statements) than unchallenged (8 percent, 20 statements). While the contributor quoted above appreciated Grendel's unique and challenging worldview, challengers perceived it as antithetical to their own belief systems: It "contain[ed] many anti-government, anti-God, and anti-religion statements." ${ }^{43}$ The Chilean military government censored The Revolt of the Masses "based on ignorance of content," an ironic inversion of the contributor's praise for its enlightening value. ${ }^{44}$

\section{Concept 6: Intellectual Influence and Appeal}

Given the professions of the contributors, it is unsurprising that many books submitted to the exhibit inspired their readers on an intellectual level. Informative, thought-provoking books that satisfied-or provoked — contributors' intellectual curiosity abounded in the exhibit: in fact, the two themes in this category were by far the most frequently occurring overall. The books whose statements included these two themes tended to be nonfiction more often than fiction; however, that trend was less consistent among the challenged books than the unchallenged.

\section{Intellectually Inspiring/Factual Learning}

This theme encompasses the large number of statements about books that educated their contributors about an interesting topic. However, it also goes beyond the learning of factual information to include statements acknowledging books that were intellectually stimulating more generally. Books that encouraged further learning, that modeled exceptional work in a particular field, or that left their readers with a 
sense of discovery-thought-provoking books of all types-were praised throughout the exhibit, and this theme summarizes the myriad ways that they appealed.

Alan Lightman's novel Einstein's Dreams encouraged me to develop a keener interest in science, a subject that once eluded me and now inspires me. (BTI V)

Albert Hourani's A History of the Arab Peoples should be required reading for anyone concerned about the Middle East. Many of the current events of today have their roots in the past, but often a less distant past than we imagine. Hourani puts it all in perspective. (BTI V)

For me The Image [A Guide to Pseudo-Events in America] thus poses an exciting intellectual challenge: adopting its remarkably useful descriptive concepts must not foreclose engaging its normative point of view. (BTI IV)

This was the most frequently occurring theme, appearing in 100 (34 percent) of the contributors' statements. It appeared in a much higher percentage of statements referring to unchallenged books (36 percent, 89 statements) than of those referring to challenged books (23 percent, 11 statements). While most of the unchallenged books in this category were nonfiction, several of the challenged were novels such as The Adventures of Huckleberry Finn (BTI II) and The Grapes of Wrath (BTI VII), whose well-developed historical and sociological contexts readers found instructive. Some of the nonfiction in this category, meanwhile, was challenged for its perceived threat to established values and institutions, such as On the Origin of Species (BTI I, II). The most direct antithesis to this theme appeared in challenges that disputed the factuality of the book. The Rape of Nanking, for example, was praised for "present [ing] a little-known piece of history" (BTI V), but challenges against it contended that that presentation was "inaccurate,' 'distorted,' and 'erroneous."'45

\section{Professionally Inspiring}

Many contributors named favorite books of their professions as inspirations, including both books that provided a model of exceptional work in the contributor's field and books that piqued their contributor's initial interest in a particular area of study.
[Crime and Punishment] kindled my interest in the law by making me think about society's rules and how we treat those who break them. (BTI I)*

[News About the News: American Journalism in Peril] points out many challenges in my chosen profession and has inspired me to practice the craft with a purpose and commitment to pursuing stories that make a difference. (BTI IV)

Statements referring to unchallenged books incorporated this theme much more frequently (30 percent, 76 statements) than those referring to challenged books ( 6 percent, 3 statements). The three challenged books inspired their contributors' interest in law (Crime and Punishment, BTI I), literature (Gargantua and Pantagruel, BTI I), and geology (On the Origin of Species, BTI II). Although the three books were censored in various times and places for ideological reasons, obviously none of the challenges cited their potential career influence per se among the reasons to suppress them.

\section{Concept 7: Readership}

The foregoing major concepts all focused on the content of the described books. The final recurrent definition of books that inspire was a bit different: It focused instead on the value of the books as books and on the experience of reading. Five distinct themes emerged discussing an element of readership; several statements included more than one of them. All five occurred in higher percentages among the statements about challenged books than among those about unchallenged ones.

\section{Aesthetic and Literary Value}

A number of statements praised books for their literary quality. Some mentioned the books' aesthetic value only in passing in the course of discussing other themes that made the books meaningful; others, however, extolled the artistry of their books as an end in itself.

My first encounter with James Joyce's Ulysses left me baffled. But, it drew me into a magical world through its byzantine virtuosity. (BTI III)*

[Night Flight is written] in a language beautiful while sparse. (BTI IV)

This was the theme that appeared the most 
frequently in statements about challenged books (31 percent, 15 statements), though it was less popular among the unchallenged (18 percent, 44 statements). As aesthetic value is subjective, a strong correspondence emerged between the inspirational statements and the challenges on this theme: A major focus of censorship attempts is the denial of a work's overall literary merit. While the contributor above perceived "byzantine virtuosity," Ulysses-whose 1933 case established the "defense of literary merit against charges of obscenity"-has been called "unmitigated filth and obscenity," "the supreme example of high-brow pornography," "literary jazz for 'sophisticated half-morons," and "unintelligible." ${ }^{46}$

\section{Emotional Response to Book}

Statements with this theme discussed their contributors' emotional responses to the experience of reading itself_-of being stirred by great literature or excited by a brilliant adventure.

I do recall as if it were yesterday feverishly turning pages [of Richard Halliburton's Complete Book of Marvels] in insatiable excitement. (BTI IV)

[Where the Red Fern Grows] brought tears to my eyes and true sadness to my heart. (BTI V)

This theme also appeared more frequently in statements referring to challenged books (19 percent, 9 statements) than unchallenged (12 percent, 29 statements). The challenges frequently evinced this theme (if anything, more strongly than the BTI statements did), as many of them expressed emotional reactions such as disgust, annoyance, or outrage at the books they protested. While the BTI contributor wrote that "The Poetry of Edna Saint Vincent Millay has brightened my life for many years. The closing lines of her poems can bring tears to my eyes or a smile to my heart" (BTI V), Millay was among a list of writers dismissed as "ridiculous, nonsense and a waste of time."47

\section{Canonical Value of Book}

Some statements stressed the importance of their books, mentioning their canonical value or fame. Many of these statements cited their books' historical significance or prizes and accolades received.

[One Hundred Years of Solitude is] one of the most popular and critically ac- claimed novels of the past half century ... García Márquez received OU's Neustadt International Prize for Literature in 1972 before winning the Nobel Prize in 1982. (BTI II)*

Gift from the Sea spent more than a year on the New York Times bestseller list and 47 weeks as the best selling book of the nation in 1955. (BTI III)

This theme occurred at a higher rate in statements referring to challenged books ( 17 percent, 8 statements) than in those referring to unchallenged books (4 percent, 9 statements), perhaps simply because better-known books are more likely to attract challenge attempts than more obscure ones. Correspondence between challenges and BTI statements on this theme occurred when challengers disputed the judgments of the critics and experts who praised them. For instance, One Hundred Years of Solitude has been derided as "garbage being passed off as literature." ${ }^{18}$

\section{Inspired Further Reading}

Many contributors praised books that inspired their readers to read more, either by creating a passion for a particular topic or by being the one special book that created a lifelong love of reading.

Since [reading The Labyrinth of Solitude] that day in 1971, I have never stopped reading the language I learned to love that summer in Mexico over thirty years ago. (BTI II)

I once thought our "war between the states" was 200 years old and boring. Then I read the late Bruce Catton's Reflections on the Civil War. Now my Civil War library numbers more than 100 titles. One might say that I was inspired. (BTI III)

Statements that refer to challenged books included this theme at a much higher rate (19 percent, 9 statements) than unchallenged (4 percent, 11 statements). There was no direct correspondence between this inspirational theme and the grounds for the challenges to these books-challengers opposed particular books but rarely argued that people should not read in general.

\section{Revisitable}

Finally, many statements specifically mentioned that these were books that could be read repeat- 
edly because they continued to yield new meaning or provide fresh emotional value with each new encounter.

Every couple of years I pick up [A Tale of Two Cities] again — and can't put it down, having yet to get to the bottom of it. (BTI III)*

I read Döblin's Berlin Alexanderplatz in high school. Since then it has traveled with me through twelve different apartments in five different cities and two continents. (BTI III)

As with all the themes in this category, a greater percentage of statements that referred to challenged books ( 15 percent, 7 statements) incorporated this theme than did unchallenged books' statements (9 percent, 23 statements). Few of the challenges corresponded directly to this theme (except perhaps by implication-challengers who did not want a book read in the first place presumably would not want it read again). However, A Tale of Two Cities is an example of a shared perception of a book that affects the contributor and challenger in exactly opposite ways. The contributor revels in the complexity of the work, which invites the reader to return: "This book is at once a challenge and a joy to read, but also deep and obscure. Every couple of years I pick up the book again — and can't put it down, having yet to get to the bottom of it. I look forward to a quiet time to give this book the attention it deserves" (BTI III). The challenger (a parent on behalf of a child) viewed the complexity as a discouraging factor: "Too difficult for low groups." 49

\section{DISCUSSION AND CONCLUSION}

Not every challenge found for the thirty-eight titles discussed had a direct antithesis in the reasons why their contributors found them inspiring. However, it was not to be expected that every comparison for a particular title would display two sides of the same thematic coin. Many challenges concentrated on the aspects Foerstel and others identified as the usual reasons: sexual content, violence, profanity, and religious themes. ${ }^{50}$ As Burress indicated would be the case, challengers often did "not consider the value or meaning of a work as a whole; they [made] arbitrary decisions about a book based on some single aspect of it-its language, for example, or a single episode. ${ }^{.51}$ Those objections logically would not find parallels in the reasons that the BTI contributors found their books meaningful, which usually did concentrate on the holistic or thematic aspects of their chosen books.
Moreover, it was entirely predictable that greater similarities would emerge within some themes more than others. For example, one would expect to find challenges citing the age appropriateness of books for young readers but not other age groups: No challenge would insist that a work was particularly ill-suited for a middle-aged audience while ignoring other readers. Challenges were neither expected nor found on the grounds of the more positive and noncontroversial themes, such as positive emotional value or affirmative social critique, and the specialized academic texts that comprised many of the contributions to concept 6, "Intellectual Influence and Appeal," were similarly unlikely to attract the attention of would-be censors in any significant number.

However, the hypothesis that a relationship would exist between the BTI statements praising and the challenges condemning certain books was supported. That relationship tended to take one of three forms. In the most direct form, censors specifically rejected the theme that the contributor praised-the Chilean case of Don Quixote is a perfect example, as are the challenges that contradicted the theme of age appropriateness or the many rejections of the Darwinian worldview. Second (and much more often), censors simply did not interpret the books as exhibiting the praiseworthy value or theme that the inspired readers recognized, many asserting that the books showed quite the opposite. The challengers who viewed Steinbeck's portrayals as demeaning instead of heroic, who condemned Twain for racism that the contributor viewed his novel as decrying, and who wrote off the work of Emerson and Millay not as insightful and moving but as "foolishness," all showed this second type of correspondence. The challenges reflected negative versions of these themes_but in so doing, they showed the same thematic focus as the contributors who celebrated the books. Claims that books should be suppressed for bad morals and values, inaccurate perspectives, or unwarranted social critiques indicate that values, perspectives, and social critique are among the key literary concerns to challengers and inspired readers alike. Finally, in a few cases, BTI statements and challenges managed to demonstrate the same theme despite discussing entirely different aspects of the book. Another challenge to Don Quixote shows this type of correspondence. The grounds for its censorship (incipient Lutheranism) had nothing whatsoever to do with the reason the contributor praised it (embracing subjectivity and uncertainty), yet both shared in prioritizing the worldview displayed in the book as among a reader's chief concerns. 
The content analysis of the BTI statements was performed essentially in a vacuum: The recurrent themes were grouped and the vocabulary to describe them was developed before any reference was made to the literature on readers' motivations. It is therefore striking how strongly the themes that emerged in this study reflect Ross's reasons people read:

Over and over, in published studies and in the interviews with readers in my own study, readers say: books give me comfort [Positive Emotional Value], make me feel better about myself, reassure me that I am normal and not a freak because characters in books have feelings like mine. Books provide confirmation that others have gone through similar experiences and survived [Resonance]. Books help me clarify my feelings [Introspection/Self-Examination], change my way of thinking about things [Challenged Own Worldview/Expanded Horizons], help me think through problems in my own life, help me make a decision, and give me the strength and courage to make some major changes in my own life. They give me a sense of mastery and control, give me courage to fight on, make me think that if the hero(ine) can overcome obstacles, then so can I [Heroes and Role Models], give me the hope to rebuild my life, and help me accept things I cannot change [Life Lessons]. They put me in touch with a larger more spacious world [Common Humanity and Universality; Empathy with Other Experiences; Factual Learning]. In summary, books provide a special kind of pleasure that cannot be achieved in any other way [Readership]. ${ }^{52}$

What is interesting about the BTI statements examined in this study is that readers cited those ideas as more than reasons to read for pleasure or explanations why certain books became favorites. Rather, they interpreted those themes as definitions of books that inspire, finding inspiration in all its forms-hope, encouragement, strength, independence, intellectual growth, personal improvement-in the reasons they were readers in the first place. That connection implies that seeking and finding inspiration is itself core to the reasons that people read. As academic librarians recognize the importance of leisure reading to the civic engagement and personal fulfillment of their students and seek to serve the academic mission by promoting it, it is hoped that this purpose will be remembered.

\section{References and Notes}

1. Sul H. Lee, introduction to Books That Inspire I (Norman: Univ. of Oklahoma Libraries, 2001): 2.

2. John M. Budd, Higher Education's Purpose: Intellectual and Social Progress (Lanham, Md.: Univ. Pr. of America, 2009): 2.

3. Barbara MacAdam, "Sustaining the Culture of the Book: The Role of Enrichment Reading and Critical Thinking in the Undergraduate Curriculum," Library Trends 44 (Fall 1995): 245-46; Julie Elliott, "Academic Libraries and Extracurricular Reading Promotion," Reference E User Services Quarterly 46 (Spring 2007): 34-43; Amanda Cain, "Archimedes, Reading, and the Sustenance of Academic Research Culture in Library Instruction," The Journal of Academic Librarianship 28 (May 2002): 115; Heidi Gauder, Joan Giglierano, and Christine H. Schramm, "Porch Reads: Encouraging Recreational Reading Among College Students," College \& Undergraduate Libraries 14, no. 2 (2007): 4.

4. Darwin D. Hendel and Roger D. Harrold, "Undergraduate Student Leisure Interests Over Three Decades," College Student Journal (Dec. 2004): $557-$ 68.

5. National Endowment for the Arts, Reading at Risk: A Survey of Literary Reading Interests in America, Research Division Report no. 46 (Washington, D.C.: NEA, 2004): 9, www.nea.gov/pub/ReadingAtRisk .pdf (accessed Dec. 22, 2008).

6. National Endowment for the Arts, Reading on the Rise: A New Chapter in American Literacy (Washington, D.C.: NEA, 2009): 3-5, http://arts.endow. gov/research/ReadingonRise.pdf (accessed July 23, 2009).

7. "How the New Generation of Well-Wired Multitaskers is Changing Campus Culture," The Chronicle of Higher Education, Jan. 5, 2007, Information Technology section, B12.

8. Lydia Burak, "Examining and Predicting College Students' Reading Intentions and Behaviors: An Application of the Theory of Reasoned Action," Reading Horizons 45 (Nov./Dec. 2004): 146.

9. Debra Von Sprecken and Stephen D. Krashen, "Is there a Decline in the Reading Romance?" Knowledge Quest 30 (Jan./Feb. 2002): 11-17.

10. Victor Nell, Lost in a Book (New Haven: Yale Univ. Pr., 1988); Brian Sturm, "Chapter 6: The Reader's Altered State of Consciousness," in The Readers' Advisor's Companion, ed. Kenneth D. Shearer and Robert Burgin (Englewood, Colo.: Libraries Unlimited, 2001): 97-116; Wayne A. Wiegand, "Chapter 1: Introduction: On the Social Nature of Reading," in Diana Tixier Herald, Genreflecting, 6th ed., ed. Wayne A. Wiegand (Englewood, Colo.: Libraries Unlimited, 2006): 3-14; Janice Radway, Reading the Romance: Women, Patriarchy and Popular Literature (Chapel Hill: Univ. of North Carolina Pr., 1991); Catherine Ross, "Readers' Advisory Service: New Directions," RQ 30 (Summer 1991): 503-18.

11. Catherine Ross, "Finding Without Seeking: What Readers Say About the Role of Pleasure Reading as a Source of Information," Aplis 13 (June 2000): 72-80; Alma Dawson and Connie Van Fleet, "Chapter 10: Books That Inspire: Nonfiction for a Multicultural Society," in Nonfiction Readers' Advisory, ed. Robert Burgin (Westport, Conn.: Libraries Unlimited, 2004): 176-96; Jessica Moyer, "Learning from Leisure Read- 
ing: A Study of Adult Public Library Patrons," Reference \& User Services Quarterly 46, no. 84 (Summer 2007): 69-82.

12. Ross, "New Directions," 509.

13. Margaret Bald and Ken Wachsberger, Literature Suppressed on Religious Grounds, rev. ed., Banned Books (New York: Facts on File, 2006); Nicholas J. Karolides, Literature Suppressed on Political Grounds, rev. ed., Banned Books (New York: Facts on File, 2006); Dawn B. Sova, Literature Suppressed on Sexual Grounds, rev. ed., Banned Books (New York: Facts on File, 2006); Dawn B. Sova, Literature Suppressed on Social Grounds, rev. ed., Banned Books (New York: Facts on File, 2006).

14. Lee Burress, Battle of the Books: Literary Censorship in the Public Schools, 1950-1985 (Metuchen, N.J.: Scarecrow, 1989): 13.

15. Herbert N. Foerstel, Banned in the U.S.A.: A Reference Guide to Book Censorship in Schools and Public Libraries, rev. and exp. ed. (Westport, Conn.: Greenwood, 2002): xxv.

16. Charlene C. Cain, "Librarians and Censorship: The Ethical Imperative," Louisiana Libraries 68 (Winter 2005): 6-8.

17. Keith Stavely and Lani Gerson, "We Didn't Wait for the Censor: Intellectual Freedom at the Watertown Public Library," Library Journal 108 (Sept. 1, 1983): 1655.

18. Sul H. Lee, introduction to Books That Inspire II (Norman: Univ. of Oklahoma Libraries, 2002): iv-v.

19. The databases used were Library Literature and Information Science and Library Literature and Information Science Retrospective (Wilson); LISA: Library and Information Science Abstracts (CSA); and Academic Search Elite, ERIC, Library, Information Science \& Technology Abstracts, and Professional Development Collection (EBSCO).

20. American Library Association Intellectual Freedom Committee, "The 100 Most Frequently Challenged Books of 1990-2000," www.ala.org/Template .cfm? Section=bbwlinks\& $\&$ Template $=/$ Content Management/ContentDisplay.cfm\&ContentID $=85714$ (accessed Mar. 3, 2008).

21. College Board, "101 Great Books Recommended for College-Bound Readers," www.collegeboard.com/ student/plan/boost-your-skills/23628.html (accessed Mar. 3, 2008).

22. Sova, Social Grounds, 277.

23. Burress, Battle of the Books, 259.

24. Robert P. Doyle, Banned Books: 2007 Resource Book (Chicago: ALA, 2007): 151.

25. Bald and Wachsberger, Religious Grounds, 14.
26. Burress, Battle of the Books, 222.

27. Walter C. Farrell Jr., "Black Like Me: In Defense of a Racial Reality," in Censored Books: Critical Viewpoints, ed. Nicholas J. Karolides, Lee Burress, and John M. Kean (Metuchen, N.J.: Scarecrow, 1993): 118.

28. Burress, Battle of the Books, 124.

29. Doyle, Banned Books, 109-11.

30. Robert Justin Goldstein, Political Censorship, The New York Times Twentieth Century in Review (Chicago: Fitzroy Dearborn, 2001): 409; Doyle, Banned Books, 36; Doyle, Banned Books, 50-51.

31. Bald and Wachsberger, Religious Grounds, 84.

32. Karolides, Political Grounds, 21-23.

33. Nellie Y. McKay and Dave Junker, "Literature, History, and Social Value: In Defense of Native Son," in Censored Books II: Critical Viewpoints, 1985-2000, ed. Nicholas J. Karolides (Lanham, Md.: Scarecrow, 2002): 324.

34. Burress, Battle of the Books, 270; Marci Lingo, "Forbidden Fruit: The Banning of The Grapes of Wrath in the Kern County Free Library," Libraries and Culture 38 (Fall 2003): 352.

35. Doyle, Banned Books, 82.

36. John S. Simmons, "A Look Inside a Landmark: The Outsiders," in Censored Books: Critical Viewpoints, ed. Nicholas J. Karolides, Lee Burress, and John M. Kean (Metuchen, N.J.: Scarecrow, 1993): 440-41.

37. Doyle, Banned Books, 100; Jonathon Green and Nicholas J. Karolides, Encyclopedia of Censorship, rev. ed. (New York: Facts on File, 2005): 571-72.

38. Bald and Wachsberger, Religious Grounds, 88.

39. Doyle, Banned Books, 135.

40. Goldstein, Political Censorship, 409.

41. Derek Jones, Censorship: A World Encyclopedia, 4 vols. (London: Fitzroy Dearborn, 2001): 649.

42. Bald and Wachsberger, Religious Grounds, 83-84.

43. Foerstel, Banned in the U.S.A., 101.

44. Jones, World Encyclopedia, 472.

45. Adam Zagorin and Frank Gibney Jr., "Fracas Follows Book About Nanking Atrocity," Time 151 (May 11, 1998): 16.

46. Jones, World Encyclopedia, 1290-1293; Kenneth R. Stevens, "Ulysses on Trial," The Library Chronicle of the University of Texas at Austin 20/21 (1982): 95; Goldstein, Political Censorship, 73.

47. Burress, Battle of the Books, 100.

48. Doyle, Banned Books, 65.

49. Burress, Battle of the Books, 337.

50. Foerstel, Banned in the U.S.A., xxv.

51. Burress, Battle of the Books, 13.

52. Ross, "New Directions," 509. 